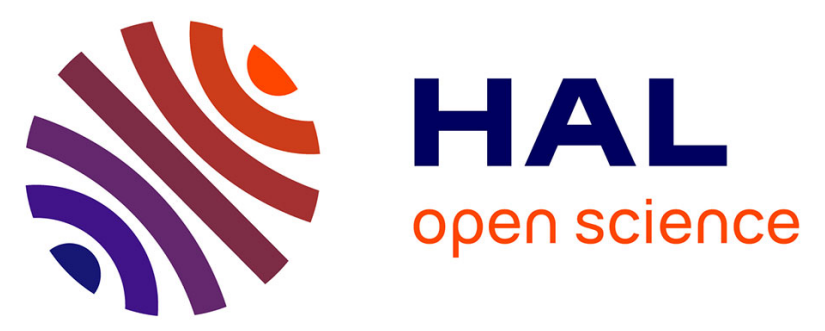

\title{
Relationship among extractive, lignin and holocellulose contents with performance index of seven wood species used for bows of string instruments
}

Eduardo Luiz Longui, Iris Brémaud, Francides Gomes da Silva Junior, Daniel Romeu Lombardi, Edenise Segala Alves

\section{To cite this version:}

Eduardo Luiz Longui, Iris Brémaud, Francides Gomes da Silva Junior, Daniel Romeu Lombardi, Edenise Segala Alves. Relationship among extractive, lignin and holocellulose contents with performance index of seven wood species used for bows of string instruments. IAWA Journal, 2012, 33 (2), pp.141-149. 10.1163/22941932-90000085 . hal-00808970

\section{HAL Id: hal-00808970 \\ https://hal.science/hal-00808970}

Submitted on 8 Apr 2013

HAL is a multi-disciplinary open access archive for the deposit and dissemination of scientific research documents, whether they are published or not. The documents may come from teaching and research institutions in France or abroad, or from public or private research centers.
L'archive ouverte pluridisciplinaire HAL, est destinée au dépôt et à la diffusion de documents scientifiques de niveau recherche, publiés ou non, émanant des établissements d'enseignement et de recherche français ou étrangers, des laboratoires publics ou privés. 


\title{
RELATIONSHIP AMONG EXTRACTIVES, LIGNIN AND HOLOCELLULOSE CONTENTS WITH PERFORMANCE INDEX OF SEVEN WOOD SPECIES USED FOR BOWS OF STRING INSTRUMENTS
}

\author{
Eduardo Luiz Longui ${ }^{1 *}$, Iris Brémaud ${ }^{2}$, Francides Gomes da Silva Júnior ${ }^{3}$, \\ Daniel Romeu Lombardi ${ }^{4}$ and Edenise Segala Alves ${ }^{5}$
}

\begin{abstract}
INTRODUCTION
The variation of anatomical features and proportions of different cell wall constituents, such as lignin and holocellulose, as well as extractives, contribute to differences found in the physical, mechanical and acoustic properties of wood (Matsunaga et al. 1996; Minato et al. 1997; Longui 2009). In this study we hypothesize that quantitative chemical contents could serve as indicators of the quality of wood for bows of string instruments. We tested this hypothesis by performing chemical analyses of samples from sticks of seven species. Studied sticks were made into bows and these bows had their playability tested by musicians.
\end{abstract}

1) Instituto Florestal, CP1322, CEP 02377-000, São Paulo, SP, Brazil [E-mail: elongui@if.sp.gov.br].

2) Laboratoire de Mécanique et Génie Civil (LMGC), CNRS - Université Montpellier II, 34095 Montpellier Cedex 5, France [E-mail: iris_bremaud@hotmail.com].

3) Departamento de Ciências Florestais da ESALQ/USP - Piracicaba, SP, Brazil [E-mail: fgomes@ esalq.usp.br].

4) Arcos Lombardi (Lombardi atelier), São Paulo, SP, Brazil [E-mail: arcos@lombardiarcos.com].

5) Instituto de Botânica, São Paulo, SP, Brazil [E-mail: edenise.alves@pq.cnpq.br].

*) Corresponding author [E-mail: elongui@if.sp.gov.br]. 
Minato et al. (1997), Matsunaga et al.(1996, 1999) and Sakai et al. (1999) observed that the impregnation of wood extractives removed from Caesalpinia echinata, the favorite wood for modern bows, reduced the vibration damping coefficient (or loss tangent, $\tan \delta$ ) in other woods. Minato et al. (2010) also observed a decrease in tan $\delta$ a parameter that quantifies the energy dissipation of a material - of wood impregnated with extractives of Brosimum sp., a possible alternative species for bows. Higher values of tan $\delta$ result in higher energy dissipation, reducing the energy that will be transferred successively to the horsehair - string - violin sounding board (Matsunaga et al. 1996; Wegst 2006). A lower damping coefficient is also a property required in woods used for the construction of several other parts of musical instruments such as xylophone keys (e.g. Aramaki et al.2007) or string instrument top plates (e.g. Ono \& Norimoto 1983; Obataya et al. 2000).

Sticks with high stiffness allow an adequate tension of the hair and better stability of the bow during playing, leading to better control by the musician (Dauchez et al. 2006; Wegst 2006; Wegst et al. 2007). Therefore, high stiffness is a quality required for bows from a musical performance point of view (Longui et al. 2010a, b). As the mass and the geometry of a bow are fixed within certain limits, the contribution of wood to bending stiffness could be described by the following performance index: $\mathrm{PI}=$ $\sqrt{M O E} / \rho$ (Wegst 2006; Wegst et al. 2007), where MOE is the modulus of elasticity and $\rho$ the density of the wood.

Brémaud et al. (2011) studied the effect of extractives on vibrational properties (damping coefficient and specific Young's modulus) in Pterocarpus soyauxii, a wood preferred for xylophones. The authors mentioned that extractives are responsible for a strong decrease in damping coefficient, and had a moderate but significant effect on wood stiffness, which is apparent when isolating the contribution of extractives to wood mass. In another study, Grabner et al. (2005) observed a trend to increase the compressive strength and elastic modulus with the increase of extractives (mostly lumen-located) in Larix hybrids.

Other studies have related lignin content with density (Trugilho et al. 1996; Vale et al. 2010) and cellulose content with the stiffness and strength of wood (Obataya et al. 2000; Fujimoto et al. 2007; Salmén \& Burgert 2008). These properties are important in wood for bows since they allow bows to be obtained with ideal weight and stiffness (Wegst et al. 2007; Alves et al. 2008). According to the same authors, balanced bows that are thin and light please musicians because they can be handled more easily. Although there are several studies that evaluate the contents of extractives, lignin and holocellulose in pulp and paper production, there are only few that correlate these contents with the physical, mechanical and acoustic properties of wood for musical instruments or accessories, such as the bows for string instruments. As already mentioned, most studies on the effect of extractives on wood for musical instruments have mainly investigated the effect of extraction or impregnation of extractives in other woods. Rarely has the correlation between extractives and other chemical constituent contents (lignin and holocellulose) with bow wood quality been examined.

Considering the importance of the chemical constituents, particularly extractives, on the characteristics of wood for bows, our goal was to investigate correlations between 
extractives, lignin and holocellulose contents and performance index (PI), for seven wood species: Caesalpinia echinata and six other potential woods for manufacturing bows for string instruments.

\section{MATERIALS AND METHODS}

\section{Material}

Five planks of Handroanthus spp., syn. Tabebuia (ipê) - Bignoniaceae and three planks of Mezilaurus itauba (itaúba) - Lauraceae, Hymenaea spp. (jatobá) - Fabaceae, Dipteryx spp. (cumaru) - Fabaceae, Diplotropis spp. (sucupira) - Fabaceae and Astronium lecointei (muiracatiara) - Anacardiaceae, were bought in the wood market in São Paulo. According to Mainieri et al. (1983), these wood species have a specific gravity above $950 \mathrm{~kg} \mathrm{~m}^{-3}$, an ideal value for modern bows (Longui 2005; Alves et al. 2008). The selection of the species utilized in this study was based on the results of Longui et al. (2010b) who analyzed the anatomy and some physical, mechanical and acoustic properties of these woods and considered them potentially suitable for bow manufacture. In addition, the legal trade and availability of these woods was another criterion used in the selection. Gasson et al. (2011) recently described the wood anatomy of some of the species tested.

During the purchase, a careful visual examination was made to exclude woods with defects and cracks. To ensure that the samples were from different trees, only one plank was purchased at random in each woodwork supply store. To confirm their identification at the time of purchase, the woods were analyzed with a $10 \times$ hand lens and later compared with samples from the Forestry Institute Xylarium (SPSFw).

From these planks, sticks $740 \times 15 \times 15 \mathrm{~mm}$ were cut for the manufacture of bows. Fifteen sticks of Handroanthus spp. were prepared, 3 from each plank and 6 from each one of the other types of wood, 2 from each plank. For Caesalpinia echinata Fabaceae, we studied wood samples donated by one of the authors. We evaluated six sticks, 3 sticks classified as high quality (class A) and 3 sticks classified as low quality (class D) for bow making (Alves et al. 2008). We studied a total of 51 sticks.

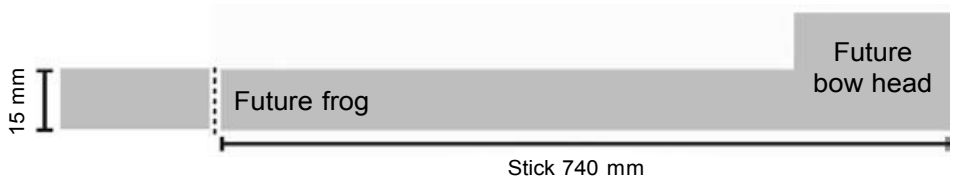

Figure 1. Schematic illustration of samples for chemical analyses and physical, mechanical and acoustical non-destructive tests.

The sticks from all species were prepared as typical blanks for bow-making, with extra-length near the future frog being used for chemical essays (Fig. 1). Thus, samples for chemical analyses were taken from adjacent to the future bow, whereas the main part (740 $\mathrm{mm}$ in longitudinal direction) was used for physical, mechanical and acoustical non-destructive tests (Alves et al. 2008 and Longui et al. 2010b). 


\section{Quantitative chemical essays}

For determination of extractives $(E x)$ and lignin $(L i)$ contents we used the TAPPI standards T204 (2004) and TAPPI T222 (2004), respectively. The samples for chemical analysis were fragmented into smaller pieces with a hammer and chisel and milled in a micro-mill. The resulting powder was sieved through 40 and 60 mesh screens, with the material retained on the last sieve used for analysis.

For extractive contents, solutions of toluene: alcohol $(2: 1 \mathrm{~V}: \mathrm{V})$ and alcohol extractions were employed, at times exceeding 12 hours in a Soxhlet Extractor. For lignin, the extractives-free powder was prepared in several stages with $72 \%$ sulfuric acid, to obtain insoluble and soluble lignin (UV-visible spectrophotometer Cary 100 Conc.). Finally, the two values of lignin were added.

$E x$ and $L i$ were expressed as a percentage (\%) of oven-dry weight of un-extracted wood. Then, the holocellulose $(\mathrm{Ho})$ content was determined by the expression:

$$
H o=[100-(E x+L i)]
$$

In addition, the proportion of lignin and hollocellulose $(\mathrm{Li} / \mathrm{Ho})$ of extractives-free wood could be useful in order to analyze specifically the contribution of cell-wall constitutive polymers.

\section{Previously determined properties ( $\rho, v$ and $M O E)$}

The specific gravity $(\rho)$, ultrasound stress wave velocity $(v)$ and dynamic elasticity modulus (MOE) data for C. echinata were obtained from Alves et al. (2008) and data of the other six woods were obtained from Longui et al. (2010b).

Specific gravity was determined from the relation between the stick mass and volume of water displaced when it was immersed in a graduated cylinder containing water. Calculation: $\rho=\mathrm{Wu} / \mathrm{Vu}$, where $\rho=$ specific gravity $\left(\mathrm{kg} \mathrm{m}^{-3}\right), \mathrm{Wu}=$ oven-dry weight of wood $(\mathrm{kg}), \mathrm{Vu}=$ dry volume of $\operatorname{wood}\left(\mathrm{m}^{3}\right)$.

The ultrasound stress wave velocity was determined using the G. Lucchi Elasticity Tester, an instrument which is used by instrument and bow makers. The tester emits an ultrasonic pulse from a transducer placed in contact with one end of the stick, and the pulse is detected by a receiver placed at the other end. The stick length was determined with measuring tape. Then, the ultrasound velocity according to Lucchi (1986) was calculated: $\mathrm{v}=\mathrm{m} / \mathrm{s}$, where $\mathrm{v}=$ ultrasound stress wave velocity $\left(\mathrm{m} \mathrm{s}^{-1}\right), \mathrm{m}=$ stick length (meters), $\mathrm{s}=$ time for the ultrasonic pulse to pass through the stick (seconds).

Considering the values of specific gravity and ultrasound velocity, the dynamic modulus of elasticity was calculated by the formula: $\mathrm{MOE}=\left(\mathrm{v}^{2} / 100\right) \times \rho$, where MOE $=$ dynamic modulus of elasticity $(\mathrm{MPa}), \mathrm{v}=$ velocity $\left(\mathrm{m} \mathrm{s}^{-1}\right), \rho=$ specific gravity $\left(\mathrm{kg} \mathrm{m}^{-3}\right)$.

\section{Performance index from the previously determined properties}

From values of dynamic modulus and of specific gravity, we also calculated the Performance index $(\mathrm{PI}=\sqrt{M O E} / \rho)$ as proposed by Wegst (2006) and Wegst et al. (2007), which describes the bending stiffness for a bow of given mass and geometry. 


\section{Statistical analysis}

The results of chemical constituents were evaluated by analysis of variance (ANOVA) between different species (and qualities in the case of C. echinata). In case of a significant difference, Tukey's Test was applied to identify the pair determinants of differences. Then the correlations among chemical constituents and the performance index were tested by linear regression analysis.

\section{RESULTS}

\section{Variations in chemical contents}

Figure 2 shows the variation in contents of extractives, lignin and holocellulose in the seven wood species studied (including 2 classes for $C$. echinata). The extractive content was higher in C. echinata (both in classes A and D) and the lowest value occurred in Diplotropis spp. The highest contents of lignin occurred in Handroanthus spp., M. itauba and Dipteryx spp. The holocellulose content was higher in Diplotropis spp., the other woods were not statistically different.

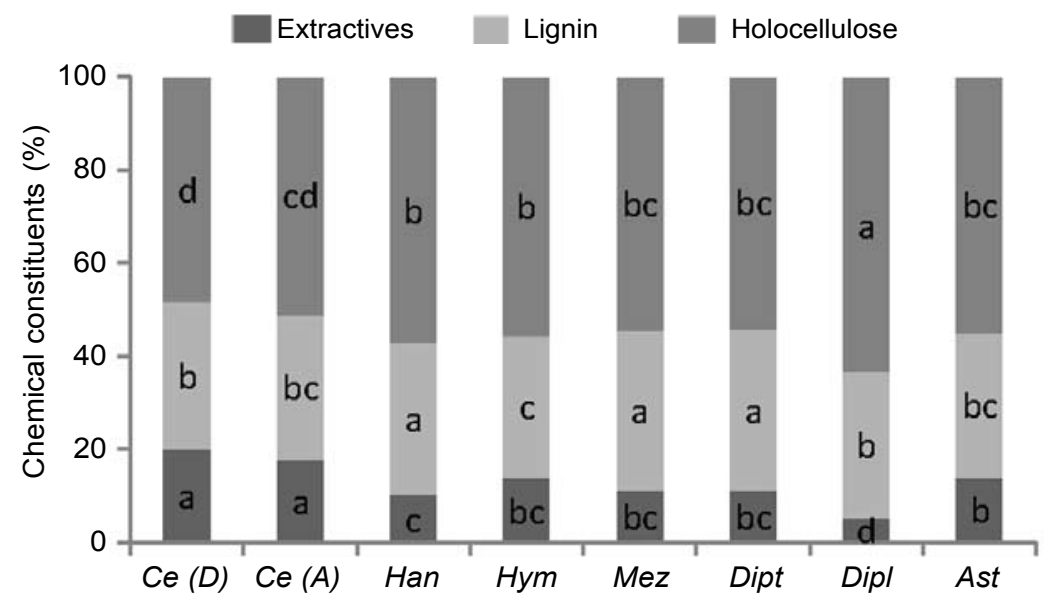

Figure 2. Variation in extractives, lignin and holocellulose contents. Ce (class D) $=$ Caesalpinia echinata low quality for bows, Ce (class A) $=C$. echinata high quality for bows, Han = Handroanthus spp., Hym = Hymenaea spp., Mez = Mezilaurus itauba, Dipt = Dipteryx spp., Dipl $=$ Diplotropis spp., Ast $=$ Astronium lecointei.- Distinct letters differ statistically at $(\mathrm{p}<0.001)$ by Tukey Test.

\section{Correlations between chemical contents and performance index}

The linear regression analysis revealed that $C$.echinata showed negative correlations among extractives and lignin with performance index, whereas positive correlations were observed between holocellulose and performance index. Extractive content also showed negative correlations with performance index in the woods of Handroanthus sp. and Astronium lecointei. In other woods there were no significant relationships. 


\section{DISCUSSION}

We choose to relate the chemical constituents with performance index (PI), because it employs three properties essential to the stick's quality (MOE, $v$ and $\rho$ ). We observed that extractives content negatively influenced the PI of C.echinata, the preferred wood for bows, Handroanthus, wood with high potential for bow manufacture (Longui et al. 2010a) and A. lecointei that has wood that lacks the necessary properties for bows (Longui et al. 2010b). Extractives did not correlate positively with PI in any of the studied woods. There is no statistically significant variation between the extractive content of the classes A and D of C. echinata, despite the lowest values occurring in class D. Schimleck et al. (2009), examining samples of $C$. echinata for violin bows of three distinct qualities, found a negative trend between high extractives content and the quality grading of the sticks.

However, C. echinata (the reference wood for bows) has the highest extractive contents (Fig. 2), so extractives content must have some effect on wood properties. One possible explanation was mentioned by Matsunaga and Minato (1998), who suggested that extractives have major roles in maintaining bow curvature and determining the low damping coefficient found in C.echinata, both desirable qualities in bow woods. Moreover, about 10-15\% of extractives are sufficient to strongly decrease the damping coefficient, whereas specific MOE continuously decreases with increasing extractives content, due to the added weight (Matsunaga et al. 1999). This suggests that there may be a kind of threshold, insuring some trade-off between conservation of elastic properties, and decreased damping.

On the other hand, Brémaud et al.(2011), studying Pterocarpus soyauxii, an African hardwood with high extractive content and a preferred material for xylophones, suggested that its extractives have a moderate but significant effect on stiffening wood, depending on the orientation of the grain and/or microfibrils. Some extractives may be able to increase wood rigidity, but mostly in the transverse direction (Minato et al. 2010), whereas in the longitudinal direction, their effect would be quite negligible compared to that of the very stiff cellulose microfibrils.

Lignin provides stiffness to the secondary cell wall and cohesion between cells, and consequently to wood tissue (Carpita \& McCann 2000), and it has a strong influence on mechanical properties of wood in the transverse directions (e.g. Nakajima et al. 2009). However, as its elastic modulus is at least 30 times smaller than that of cellulose microfibrils, its contribution to wood MOE along the grain and/or for small microfibril angle remains small (Obataya et al. 2000; Bergander \& Salmén 2002).

The higher lignin content of Handroanthus, M. itauba and Dipteryx, which is intuitively related to greater stiffness, do not correspond with the MOE values obtained from the sticks analyzed in the present study. Longui et al. (2010b) found that Handroanthus and $M$. itauba had the lowest MOE values, while Dipteryx had the highest together with $C$. echinata. Therefore, lignin content does not seem to have a clear influence on stick quality, as far as PI is concerned. The only significant relationship observed with PI was a negative one in C.echinata. This suggests lower lignin content for wood quality for bows, but $C$. echinata did not differ significantly from A. lecointei, which in practice did not provide good bows. 
Within species, PI correlated positively with holocellulose content in C. echinata, since higher values of holocellulose were associated with higher values of bending stiffness. However, C. echinata had the lowest holocellulose concentration compared to the six other woods, but showed higher values of MOE. Obataya et al. (2000), Fujimoto et al. (2007) and Salmén \& Burgert (2008) indicate a positive relation between the proportion of cellulose microfibrils and the stiffness and strength of wood.

The quality of the bows made with C.echinata was tested in practice. In addition to C.echinata, Handroanthus and Dipteryx also provided quality bows, well accepted by Brazilian musicians. This study compared only the content of extractives, lignin and holocellulose; however, it is possible that a study on the different types of extractives, lignin, the different sugars that form holocellulose (cellulose and hemicellulose), and the degree of crystallinity, can reveal important information on what affects the quality of these woods and expand knowledge about bow manufacture. Moreover, taking into account other properties, particularly viscoelastic ones, closer relationships may be revealed between chemical contents and mechanical properties relevant for bow making. Quantitative chemical contents can be quite good indicators of vibration damping (Brémaud et al.2010), and they might also be when considering creep and heat-bending properties.

\section{CONCLUSION}

The wood quality of a bow stick cannot be explained solely by the content of extractives, lignin and holocellulose since they varied significantly among the two woods with highest potential (Handroanthus and Dipteryx) and reference wood for modern bows (C.echinata). Extractive content was negatively correlated with PI in Caesalpinia echinata, Handroanthus sp. and Astronium lecointei. In C. echinata holocellulose was positively correlated with PI. These results need to be further explored with more samples.

\section{REFERENCES}

Alves, E.S., E.L. Longui \& E. Amano. 2008. Pernambuco wood (Caesalpinia echinata) used in the manufacture of bows for string instruments. IAWA J. 29: 323-335.

Aramaki, M., H. Baillères, L. Brancheriau, R. Kronland-Martinet \& S. Ystad. 2007. Sound quality assessment of wood for xylophone bars. J. Acoust. Soc. Amer. 121: 2407-2421.

Bergander, A. \& L. Salmén. 2002. Cell wall properties and their effects on the mechanical properties of fibers. J. Mater. Sci. 37: 151-156.

Brémaud, I., N. Amusant, K. Minato, J. Gril \& B. Thibaut. 2011. Effect of extractives on vibrational properties of African Padauk (Pterocarpus soyauxii Taub.). Wood Sci. Technol. 45: 461-472.

Brémaud,I., K. Minato, P. Langbour \& B. Thibaut. 2010. Physico-chemical indicators of the interspecific variability in vibration damping of wood. Ann. For. Sci. 67: 707-713.

Carpita, N. \& M. McCann. 2000. The cell wall. In: B.B. Buchanan, W. Gruissem \& R.L. Jones (eds), Biochemistry \& Molecular Biology of Plants: 52-109. American Society of Plant Physiologists, Rockville.

Dauchez, N., J.-M. Génevaux \& I. Brémaud. 2006 Qualité des archets de violon et instabilité de type flambement [in French]. In: 8e Congrès Français d'Acoustique, Tours, France: $459-462$. 
Fujimoto, T., H. Yamamoto \& S. Tsuchikawa. 2007. Estimation of wood stiffness and strength properties of hybrid larch by near-infrared spectroscopy. Appl. Spectroscopy 61: 150-170.

Gasson, P., P. Baas \& E.A. Wheeler. 2011. Wood anatomy of CITES-listed tree species. IAWA J. 32: $155-198$.

Grabner, M., U. Müller, N. Gierlinger \& R. Wimmer. 2005. Effects of heartwood extractives on mechanical properties of larch. IAWA J. 26: 211-220.

Longui, E.L. 2005. Pau-brasil e outras espécies nativas empregadas na confecção de arcos para instrumentos de corda: um estudo comparativo [in Portuguese]. 75 pp. Dissertação (Mestrado em Biodiversidade vegetal e meio ambiente). Instituto de Botânica de São Paulo.

Longui, E.L. 2009. Potencial de madeiras nativas na fabricação de arcos para instrumentos de corda [in Portuguese]. 144 pp. Tese (Doutorado em Biodiversidade vegetal e meio ambiente). Instituto de Botânica de São Paulo.

Longui, E.L., D.R. Lombardi \& E.S. Alves. 2010b. Potential Brazilian wood species for bows of string instruments. Holzforschung 64: 511-520.

Longui E.L., T. Yojo, D.R Lombardi \& E.S. Alves. 2010a. The potential of ipê (Handroanthus spp.) and maçaranduba (Manilkara spp.) woods in the manufacture of bows for string instruments. IAWA J. 31: 149-160.

Lucchi, G. 1986. The use of empirical and scientific methods to measure the velocity of propagation of sound. J. Violin Soc. Amer. 9: 107-123.

Mainieri, C., J.P.Chimelo \& V.Angyalossy-Alfonso. 1983. Manual de identificação das princi-pais madeiras comerciais brasileiras. Promocet, Instituto de Pesquisas Tecnológicas, São Paulo.

Matsunaga, M. \& K. Minato. 1998. Physical and mechanical properties required for violin bow materials II: Comparison of the processing properties and durability between pernambuco and substitutable wood species. J. Wood Sci. 44: 142-146.

Matsunaga, M., K. Minato \& F. Nakatsubo. 1999. Vibrational property changes of spruce wood by impregnation with water-soluble extractives of pernambuco (Guilandina echinata Spreng.). J. Wood Sci. 45: 470-474.

Matsunaga, M., M. Sugiyama, K. Minato \& M. Norimoto. 1996. Physical and mechanical properties required for violin bow materials. Holzforschung 50: 511-517.

Minato, K., Y. Konaka, I. Brémaud, S. Suzuki \& E. Obataya. 2010. Extractives of muirapiranga (Brosimum sp.) and its effects on the vibrational properties of wood. J. Wood Sci. 56: 41-46.

Minato, K., K. Sakai, M. Matsunaga \& F. Nakatsubo. 1997. The vibrational properties of wood impregnated with extractives of some species of Leguminosae. Mokuzai Gakkaishi 43: $1035-1037$.

Nakajima, M., Y. Furuta, Y. Ishimaru \& M. Ohkoshi. 2009. The effect of lignin on the bending properties and fixation by cooling of wood. J. Wood Sci. 55: 258-263.

Obataya, E., T. Ono \& M. Norimoto. 2000. Vibrational properties of wood along the grain. J. Mater. Sci. 35: 2993-3001.

Ono, T.\& M. Norimoto. 1983. Study on Young's modulus and internal friction of wood in relation to the evaluation of wood for musical instruments. Jap. J. Appl. Phys. 22: 611-614.

Sakai, K., M. Matsunaga, K. Minato \& F. Nakatsubo. 1999. Effects of impregnation of simple phenolic and natural polycyclic compounds on physical properties of wood. J. Wood Sci. 45: 227-232.

Salmén, L. \& I. Burgert. 2008. Cell wall features with regard to mechanical performance. A review. Holzforschung 63: 121-129.

Schimleck, L.R., C. Espey, C.R. Mora, R. Evans, A. Taylor \& G.I.B. Muniz. 2009. Characterization of the wood quality of pernambuco (Caesalpinia echinata Lam.) by measurements of density, extractives content, microfibril angle, stiffness, color, and NIR spectroscopy. Holzforschung 63: 457-463. 
TAPPI. 2004. T 204-om97. Solvent extractives of wood and pulp. In: Tappi Test Methods. TAPPI Press, Norcross, $4 \mathrm{pp}$.

TAPPI. 2004. T 222-om02. Acid-insoluble lignin in wood and pulp. In: Tappi Test Methods. TAPPI Press, Norcross, $5 \mathrm{pp}$.

Trugilho, P.F., J.T. Lima \& L.M. Mendes. 1996. Influência da idade nas características físicomecânicas e anatômicas da madeira de Eucalyptus saligna. Cerne 2: 97-111.

Vale, A.T., I.S. Dias \& M.A.E. Santana. 2010. Relações entre propriedades químicas, físicas e energéticas da madeira de cinco espécies de Cerrado. Ciência Florestal 20: 137-146.

Wegst, U.G.K. 2006. Wood for sound. Amer. J. Bot. 93: 1439-1448.

Wegst, U.G.K., S. Oberhoff, M. Weller \& M.F. Ashby. 2007. Materials for violin bows. Int. J. Mater. Res. 98: 1230-1237. 